\title{
BUSINESS AND HUMAN RIGHTS IN TIMES OF GLOBAL EMERGENCIES: A COMPARATIVE PERSPECTIVE
}

\begin{abstract}
This article provides an overview of the key principles of the state's fulfilmentt of the positive obligation to protect human rights from violations by business during the crisis caused by COVID 19: balancing the need to ensure public health and human rights protection; balancing the competing rights of non-state actors with taking into account the concept of the right to security as freedom from fear and freedom from want; implementation of the international human rights law requirement on restriction of human rights, including the derogation from international human rights obligations.

The second part of the article is an overview of the results of a survey on the implementation by various countries around the world of the obligation to protect human rights from business violations during COVID 19. The purpose of the survey was to summarize the information about different countries obtained according to the proposed criteria to identify the main regulatory models that states use to fulfil their obligation to protect human rights from business violations in time of COVID 19.
\end{abstract}

* Assistant Professor, Head of the International Lab on Business and Human Rights in Yaroslav Mudryi National Law University (Ukraine), Fulbright Visiting Scholar 2019-2020; ORCID: 0000-0003-3199-7790; e-mail: uvarova.info@gmail.com. 


\section{Keywords}

business and human rights - state's obligation to protect - regulatory model - global emergency - international human rights obligation

\section{INTRODUCTION}

The pandemic of infectious diseases has been called "the greatest threat to humanity", and many scientists have expressed "concern that the world is not ready to cope with a major pandemic of infectious diseases", long before its occurrence ${ }^{1}$.

The COVID-19 pandemic has changed our world. Everyone has been touched. And everyone has own story to share. There are threats to life and health, waves of misinformation, loss of jobs or earnings, increased government control, including through mobile apps developed by business, increased burdens of caring for children and family members, shutdowns of businesses, supply chain disruptions, impossibility of free movement, corruption scandals and unfair competition, high prices for essential goods and services, incidents of discrimination, harassment, and persecution, and many other risks to human rights ${ }^{2}$. The scale of challenges posed by COVID-19 spread to all areas of relationship, creating new risks of negative human rights impacts by business and increasing the vulnerability of many people. For employees, consumers, customers, suppliers, for communities where business operates, a responsible

1 B. Walsh, "The World is Not Ready for the Next Pandemic", Time Magazine, 2017, issue 18, p. 189, available at time.com/magazine/us/4766607/may-15th-2017-vol-189no-18-u-s/ [last accessed 15.06.2020].

2 See ITUC Global COVID-19 Survey: Half of countries in lockdown as COVID-19 pandemic wreaks health and economic havoc on working people and their families, available at https://www.ituc-csi.org/ituc-global-covid-19-survey [last accessed 15.06.2020]; COVID-19: How human rights can help protect us, available at https:/ / www. amnesty.org/en/latest/news/2020/03/coronavirus-how-human-rights-help-protect-us/ [last accessed 15.06.2020]; Calibrating Human Rights and Necessity in a Global Public Health Emergency: Revive the UN OHCHR's ICESCR Compliance Criteria, available at ejiltalk.org/calibrating-human-rights-and-necessity-in-a-global-public-health-emergencyrevive-the-un-ohchrsicescr-compliance-criteria/ [last accessed 15.06.2020]. 
human rights conduct amid the global challenge has become especially important.

The pandemic, coupled with the economic recession, has presented governments and businesses with a challenge: how can the economy be supported and the standards of responsible business conduct be maintained?

The UN Secretary-General, Antõnio Guterres, stressed the importance of building more inclusive and sustainable economies, focusing on the most vulnerable groups, and striving for a better world after the Covid-19 pandemic and its shattering consequences are faced down ${ }^{3}$. Given the current extreme conditions, the relevance and importance of the UN Guiding Principles on Business and Human Rights ${ }^{4}$ have increased. The values they reflect should become the basis of our search for adequate answers to the challenges we face today ${ }^{5}$. Their implementation requires that responsible governments and businesses ensure policy coherence, cooperation, transparency, and their own accountability. The Guiding Principles are grounded on the three key concepts:

I. The state duty to protect against human rights abuse by third parties, including businesses (in particular, by ensuring the effective, nation-wide implementation of the internationally recognized human rights standards).

II. The corporate responsibility to respect human rights, including due diligence about possible negative impacts of certain business activity on human rights, with regard to potential adverse impact on human rights that they may cause or contribute to.

III. Access to effective remedies.

${ }^{3}$ Recovery from the coronavirus crisis must lead to a better world by Antonio Guterres, available at www.un.org/sg/en/content/sg/articles/2020-04-02/recoverythe-coronavirus-crisis-must-leadbetter-world. [last accessed 15.06.2020].

${ }^{4}$ See the text of the UN Guiding Principles on Business and Human Rights in Ukrainian (unofficial translation; the Ministry of Justice of Ukraine and Yaroslav Mudryi National Law University), available at https://legalforum.nlu.edu.ua/wp-content/ uploads/2019/06/kerivni-principi-oon.pdf. [last accessed 15.06.2020].

${ }^{5}$ Shaping a new social contract through the pandemic, available at https://www. business-humanrights.org/en/shaping-a-new-social-contract-through-the-pandemic. [last accessed 15.06.2020]. 
This article is aimed to compare models of law regulation used by States to meet their obligations to protect human rights from business violations, taking into account the additional challenges associated with COVID 19. To achieve this aim an overview was conducted of the key principles of the state's fulfilment of the positive obligation to protect human rights from violations by business during the crisis caused by COVID 19 and the survey on the implementation of the obligation to protect human rights from business violations by various countries around the world during COVID 19.

\section{The Obligation of States to Protect human RIGHTS FROM BUSINESS VIOLATIONS}

The state has traditionally been seen as a bearer of human rights responsibilities ${ }^{6}$. Initially, this was owing to the fact that the state was seen as the main threat to human rights, and therefore it was the addressee to whom the requirement to respect human rights is addressed. This aspect of the relationship between the human and the state, which remains relevant today, was gradually supplemented by requirements to protect (including from violations by third parties) and ensure the fulfilling of human rights. Accordingly, the mechanism of human rights protection was formed in such a way that the state is both a threat from which a person should be protected and an instrument called to provide such protection.

That is why the state's human rights obligations are central to the idea of human rights. They cover the prohibition of state interference in the sphere of individual freedom, as well as the requirements for respect for human rights and the protection of human rights from violations by the third parties ${ }^{7}$.

${ }^{6}$ Р. Алексі, Інституціоналізація прав людини в демократичній конституційній державі. Філософія прав людини ; за ред. Ш. Госепата та Г. Ломанна ; пер. 3 нім. О. Юдіна та Л. Доронічевої. К. : Ніка-Центр, 2008, s. 172-190. [R. Aleksi, Instytutsionalizatsiya prav lyudyny $\mathrm{v}$ demokratychniy konstytutsiyniy derzhavi. Filosofiya prav lyudyny ; za red. SH. Gosepata ta G. Lomanna ; per. z nim. O. Yudina ta L. Doronichevoyi. K. : Nika-Tsentr, 2008, s. 172-190].

${ }^{7}$ Г. О. Христова, Позитивні зобов'язання держави у сфері прав людини: сучасні виклики: монографія. Харків: Право, 2018, с. 433 [Н. О. Khrystova, Pozytyvni 
During the second half of the XX century, under the influence of various processes, primarily globalization, the influence of non-state actors on human rights became more and more noticeable. The issue of such influence was especially acute at a time when states were unable to fulfil their role as instruments of human rights protection. It is absolutely obvious that companies - whether local or multinational, public or private - have a significant impact on human rights, both positively and negatively. Business operations can affect different actors workers, migrants, vulnerable groups (children, people with disabilities, elderly people etc.) - in different ways (discrimination, exploitation, environmental damage, etc.) and within various types of economic activity (agriculture, textile industry, oil and gas industry, financial, educational, medical services, etc.). Businesses are required to respect human rights in doing business both within and outside national borders in such a way as to prevent and avoid any potential direct or indirect negative impact ${ }^{8}$.

Human rights are usually affected first by a global crisis - 'the most serious and systematic human rights violations occur in times of emergencies when countries use emergency powers to address threats to public order and security' ${ }^{\prime}$. A government facing a global challenge - an armed conflict, civil war, severe economic turmoil, natural disaster, or other similar threat - faces the need to restrict certain rights and freedoms. The pandemic is one of such challenges. In these very moments, the state's commitment to human rights and the effectiveness of their protection are being tested. In today's world, doing business is also a test: its impacts on people's daily lives are no less significant than those of the state. «The

zobov"yazannya derzhavy u sferi prav lyudyny: suchasni vyklyky: monohrafiya. Kharkiv: Pravo, 2018, s. 433].

${ }^{8}$ C. M. O'Brien, Business and human rights: a handbook for legal practitioners, Council of Europe Publishing, 2018, available at https://www.coe.int/en/web/ nationalimplementation/publications/handbooks?fbclid=IwAR29oo9XI_6Jj9A6dhH mGTDp7RzoQX5vBueoH-o8I1MPjBxpcdGI9E-zSc [last accessed 15.06.2020]. See also Report of the Special Representative of the Secretary-General, Protect, Respect and Remedy: A Framework for Business and Human Rights, UN Doc A/HRC/8/5, 7 April 2008, available at http://www. reports-and-materials.org/sites/default/files/reportsandmaterials/Ruggie-report-7- Apr-2008.pdf [last accessed 15.06.2020].

9 E. J. Criddle, E. Fox-Decent, "Human Rights, Emergencies, and the Rule of Law", Human Rights Quarterly, 2012, Vol. 34, No. 1, pp. 39-87. 
pandemic has fundamentally altered the global ways of doing business, resulting in decreases of production, demand and consumption, distortion of global supply chains, and threats to the socio-economic survival of the most vulnerable» ${ }^{10}$. «How businesses respond to the crisis-especially those firms which receive state support to continue operations - will shape public attitudes towards the private sector for years to come» ${ }^{11}$.

In the case of COVID 19, states should find a reasonable balance between ensuring public good (public health and safety) and individual rights and freedoms. The difficulty is that it is a question of a whole set of rights and freedoms (rather than separate rights as happens usually). A number of rights - freedom of movement, property rights, freedom of peaceful assembly and many others - need to be restricted in order to achieve a legitimate aim.

As the world plunges into the worst recession it has seen since the Great Depression of the 1930s, the International Labour Organization estimates that $81 \%$ of the global workforce, or 2.7 billion workers worldwide, have felt the effects of COVID-19-related measures ${ }^{12}$. Many have been placed under lockdown and forced to shut down businesses, inevitably leaving the poorest and most vulnerable members of society to bear the brunt of the economic consequences. Suddenly, we have been forced to re-evaluate the meaning of "essential" as we depend on everyday cleaning staff, caregivers, grocery store workers, and mass transport employees to sustain our collective life and survival. These frontline workers face a disproportionate risk of disease exposure as they shoulder the responsibility of manufacturing masks, transporting food, caring for the sick, and collecting trash - all while working with few or no safety nets, and often being trapped in exploitative contracts.

${ }^{10} \mathrm{~J}$. Letnar Černič, "Coronavirus, human dignity and the new normality", available at https://www.cambridge.org/core/blog/2020/04/02/coronavirus-human-dignityand-the-new-normality/ [last accessed 15.06.2020].

${ }^{11}$ Human Rights Due Diligence and COVID-19: Rapid Self-Assessment for Business, available at https:/ / www.undp.org/content/undp/en/home/librarypage/democraticgovernance/human-rights-due-diligence-and-covid-19-rapid-self-assessment-for-business. html [last accessed 15.06.2020].

12 COVID-19 responses must be built on human solidarity, ILO tells World Bank/ IMF, available at https://www.ilo.org/global/about-the-ilo/newsroom/news/WCMS _741905/lang--en/index.htm [last accessed 15.06.2020]. 
As stated in the UN Guiding Principles on Business and Human Rights, States must enforce laws that are aimed at, or have the effect of, requiring business enterprises to respect human rights. These include labour protection measures for workers, beginning with an adequate minimum wage floor, paid sick leave, maximum working hours, and provision of necessary personal protective equipment to secure the right to health. Furthermore, States must pay special attention to workers in informal sectors, the "gig" economy, and migrant workers, who face greater risks of exploitation and endangerment - extending safeguards for their human rights and dignity, as well as ensuring basic income protection $^{13}$. Crucially, as was recalled by the UN Working Group on Business and Human Rights, these principles continue to apply in the context of a crisis. In fact, as the recognized and authoritative framework for State duties and business responsibilities in preventing and addressing adverse business-related human rights impacts, respecting their guidance is more important than ever ${ }^{14}$.

The preliminary thesis of the need to find a reasonable balance between the common good of public health and safety, on the one hand, and individual rights, on the other, while balancing the individual rights of non-state actors, should be considered in the context of ensuring the right to security.

The right to security should include freedom from fear and freedom from want. This concept views these two freedoms as complementary and interdependent. As identified by UNDP in 1994, threats to human security are not necessarily linked to international wars and do not necessarily arise during armed conflict ${ }^{15}$. They should also include those

${ }^{13}$ C. Sun, "Business and human rights: 'building back better' from COVID-19", available at https://www.universal-rights.org/blog/business-and-human-rightsbuilding-back-better-from-covid-19/ [last accessed 14.07.2020].

${ }^{14}$ Ensuring that business respects human rights during the Covid-19 crisis and beyond: The relevance of the UN Guiding Principles on Business and Human Rights, Statement by the UN Working Group on Business and Human Rights, available at https:/ / www.ohchr.org/EN/NewsEvents/Pages/DisplayNews.aspx?NewsID=25837\&LangID=E [last accessed 15.06.2020].

15 UNDP, 1994 Human Development Report, New Dimensions of Human Security, p. 24, available at: http://hdr.undp.org/en/media/hdr_1994_en_chap2.pdf [last accessed 15.06.2020]. 
that lead to hunger, disease, and persecution. In addition, focusing on the human individual rather than the state, the UNDP Report suggested the idea of unregulated conventions in the field of human security on what should be considered "ordinary" and "extraordinary" threatening events, providing protection, including in everyday life ${ }^{16}$. A person cannot be free if she or he fears for her or his life, physical, and psychological security, or if she or he cannot fulfil basic needs.

This thesis is reminiscent of an important element of a democratic society: a policy that benefits society, but places too much burden on the most vulnerable individuals and groups, communities is unacceptable. The fairness of the means is important as much as importance of the purpose of its implementation.

It is important to keep in mind that the economy is focused on efficiency, but human rights are focused on justice. It is extremely difficult for economic and human rights actors to agree with each other and to coordinate their concepts, although the influence on each other is significant ${ }^{17}$.

Owing to its nature, the idea of human rights is alien to business (except in cases of using it as a "social licence to operate"). It's true especially in times of crisis, when business seeks to save itself first of all. But the state, owing to its nature, is not oriented on human rights either. It is oriented on the absolutization of its power, which, however, has not prevented humanity from developing mechanisms to restrain it to protect human rights. The corporate responsibility to respect human rights should be raised in times of crises. Reverse trends are unacceptable.

The challenges associated with COVID 19 increase the collision which is laid immanently to the concept of business and human rights ${ }^{18}$ : on the one hand, we recognize the corporate responsibility to respect human rights (i.e. the negative obligation to prevent human rights violations in own operations). On the other hand, we recognize that business affects

${ }^{16}$ Ibid., p. 1.

17 M. Couret Branco, Economics Versus Human Rights, Routledge, 2014, p. 1.

18 A. Coco, T. de Souza Dias, "Part I: Due Diligence and COVID-19: States' Duties to Prevent and Halt the Coronavirus Outbreak", available at https:/ / www.ejiltalk.org/parti-due-diligence-and-covid-19-states-duties-to-prevent-and-halt-the-coronavirus-outbreak/ [last accessed 15.06.2020]. 
human rights significantly in the spheres of economic and social rights, i.e. rights that require positive actions to be realized.

It is important that human rights due diligence mechanisms should work at the decision-making level of both governmental and nongovernmental actors. Both the state and non-state actors that go beyond the established legal regulation of emergencies situations are obliged to prove their human rights prudence as much as possible in concrete situations ${ }^{19}$. Emergencies that require the abandonment of existing legal regulation ${ }^{20}$, in order to go beyond it, should be exceptional: these are those emergencies that require a decision to be made as soon as possible. No other emergency should pose a threat to the constitutional order.

At a time when the state is faced with the need to restrict certain human rights in order to ensure security, the debate on balancing two values - public security and human rights - becomes more acute. But it is important that such discussions should take place in the context of democratic legitimacy, which minimizes injustice and arbitrary violations of rights. Furthermore, compromises could not cover inalienable human rights; they should be applied only in exceptional cases, be temporary and should be limited to the most important issues ${ }^{21}$.

\section{Actions of States to Protect human Rights FROM BUSINESS VIOLATIONS DURING COVID 19}

\section{The Methodology of the Expert Survey}

The second part of the paper is an overview of the results of a survey on the implementation of the obligation by various countries around the world to protect human rights from business violations during COVID 19.

${ }^{19}$ F. Bastos, A. De Ruijter, “Break or Bend in Case of Emergency?: Rule of Law and State of Emergency in European Public Health Administration", European Journal of Risk Regulation, 2019, Vol. 10, p. 624.

20 A. Yildiz, Human Rights in a State of Emergency, available at https://blog-iaclaidc.org/2020-posts/2020/3/26/human-rights-in-a-state-of-emergency_[last accessed 15.06.2020]. See also Criddle, Fox-Decent, supra note 9, p. 59.

${ }^{21}$ S. Tripathi, "Developments in the Field Companies, COVID-19 and Respect for Human Rights", Business and Human Rights Journal, 2020, Vol. 0:0, p. 1-9. 
The purpose of the survey was not to compare countries, so I do not provide information on each country separately. I have summarized the information obtained according to the proposed criteria in order to identify the main regulatory models that states use to fulfil their obligation to protect human rights from business violations. Information about 26 countries (Southern and Northern Americas, EU, Great Britain, PostSoviet region) ${ }^{22}$ from 54 experts was collected and summarized.

All persons who participated in the survey are business and human rights experts (academics, independent experts and / or CSOs representatives). The methodology of the survey's conducting included:

1. Developing the questionnaire in Russian ${ }^{23}$ and English ${ }^{24}$. The questions were developed based on the key risks of business negative impact on human rights during the crises - a) Threat of COVID-19; b) Loss of jobs or earnings; c) Work and family balance; d) The right to privacy; e) Discrimination and stigma; f) Increased vulnerability; g) Employees of the gig economy; h) Irresponsible conduct in supply chains and others.

2. The request to participate in the survey was shared among the networks of the human rights experts, academics and civil society organizations (the Global Business and Human Rights Scholars Association, Latin American Business and Human Rights Scholars Association, Civil Solidarity Platform etc.) with brief explanation of content and goal of the survey.

3. The Post-Soviet region was in the key focus of the survey. The countries of the region have a socialist past. Many of them were a part of the Soviet Union for a long time, others bordered on it and were ruled under the Soviet regime or influenced by it very much in political and economic ways. Despite the quite different

${ }^{22}$ Austria, Argentina, Armenia, Republic of Belarus, Bulgaria, Brazil, United Kingdom, Georgia, Denmark, Italy, Canada, Kazakhstan, Kyrgyzstan, Mexico, Moldova, Netherlands, Germany, Poland, Russian Federation, Slovakia, United States, Ukraine, Finland, Czech Republic, Sweden, Switzerland.

${ }^{23}$ Available at: https:// docs.google.com/forms/d/10pX3VREXqcpGKT87ELrHdL 4K7j3ZJcs5ENxVuY_k8Xs/edit.

${ }^{24}$ Available at: https://docs.google.com/forms/d/1RNdw0fJM8egosBcPeRHCqF AllfTCN2c2hjGcvne3r90/edit. 
historical background, one faces a very similar situation regarding corporate responsibility for respecting human rights in the region. In turn, the low level of corporate respect for human rights is due to the following factors, which are also common for countries in the region, although in different degrees:

A. The absence of free private business for a long time, or concentration of State owned businesses in key sectors; strong state control of all economic processes and a large share of state participation in the economy which led to the lack of tradition for business to take responsibility and the lack of expectations of society for responsible business behaviour;

B. A long period of undemocratic political regimes in the region or being under their strong influence, leading to a lack of a tradition of understanding the values of human dignity and personal autonomy which are the core basis of corporate responsibility for respect for human rights; the idea of human rights was subordinate to state policy; collective interest prevailed over the individual/private, and legal regulation was based on the principle of the supremacy of the state will, but not on the rule of law principle;

C. The fall of undemocratic regimes allowed civil society to strengthen and develop, but the main focus of the CSOs is still the state's activities, since the state is considered the main threat to human rights. In this sense one finds very few cases in the regions when human rights defenders work with human rights abuses by business. Politicization of human rights issues is still common in the region.

The assumption which should be confirmed or disproved by the survey was the following: Post-Soviet countries use a non-BHR model of regulation because of: (a) low awareness of non-state actors, especially business, of their human rights impacts; (b) risks and challenges associated with the absence of strong democratic traditions, a high level of corruption, and low public confidence in the justice system; (c) maintaining a paternalistic approach to the respecting, protection, and fulfilment of human rights. The human rights sphere has traditionally been equated with state obligations; (d) a low level of awareness of state institutions, academic community, non-governmental organizations, 
business with the UNGPs on Business and Human Rights, developed standards and initiatives, and good practices; (e) weak state institutions on the effective protection of human rights and a high level of corruption in the public and private sectors.

\section{The Results of the Expert Survey}

The developed questionnaire included the following criteria:

1) Legislative measures taken by the state to protect workers from the risks of infection in the workplace, in particular:

- Quarantine and suspend activities of most of the companies;

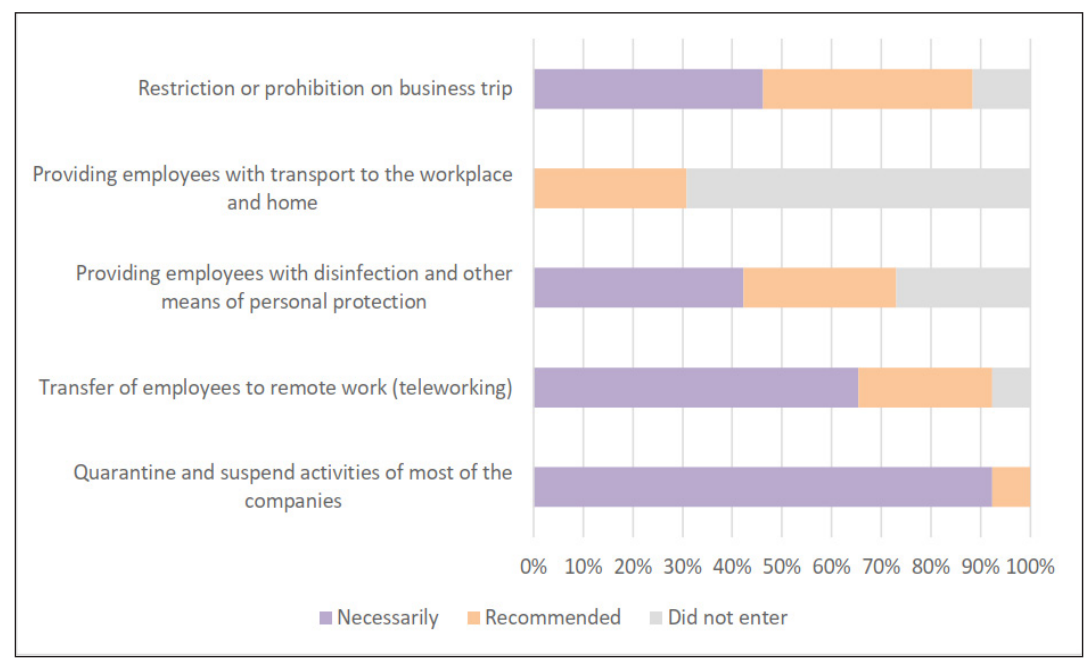

- transfer of employees to remote work (teleworking);

- providing employees with disinfection and other means of personal protection;

- providing employees with transport to the workplace and home;

- Restriction or prohibition on business trips.

It is important whether these measures are applied by the state as mandatory for business or recommendatory, or they are taken by business purely on its own initiative without any instructions, recommendations, 
or guidelines from the state and, accordingly, without its control for their implementation.

According to the survey, the most commonly used measure by states was the introduction of quarantine, when businesses that work directly with customers stopped work (except essential) owing to the introduction of mandatory requirements by the state.

Although many countries used significant restrictions (up to a total ban) on the movement of public transport at the time of quarantine, the vast majority of countries left the question of providing employees who continued to work in the workplace with transport to work and back home at the discretion of employers.

If we compare the regions, in this part the tools used by the states are very similar and no fundamental difference was found during the survey.

2) State's applying measures aimed at protecting employees from dismissal and / or loss of earnings during quarantine, which may include:

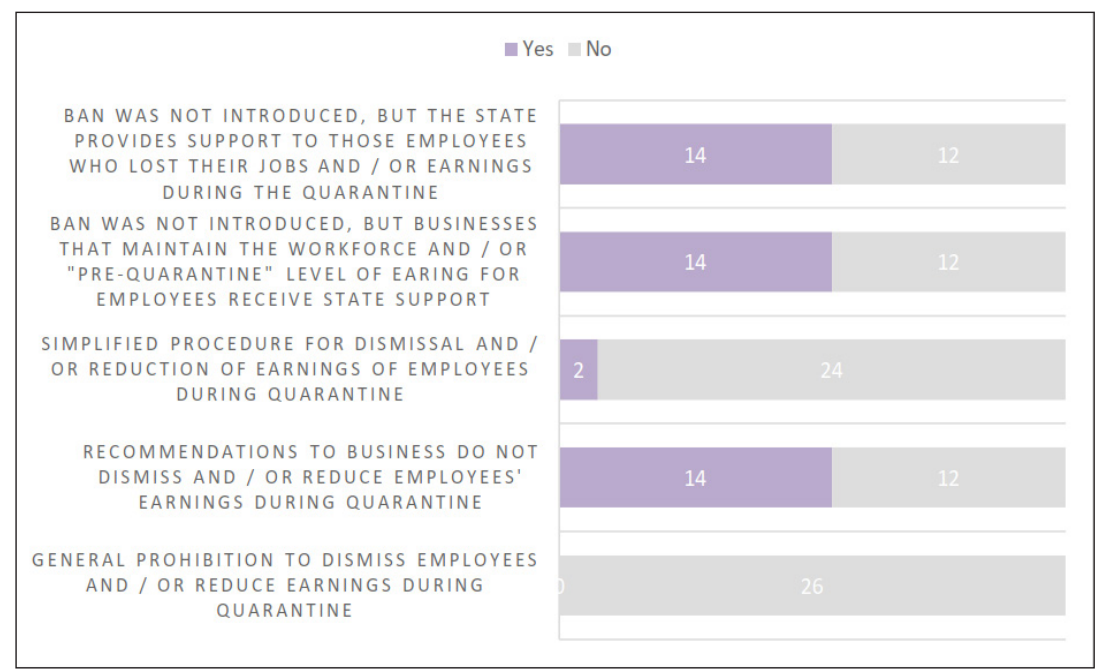

- general prohibition of dismissing employees and / or reducing earnings during quarantine;

- recommendations to business not to dismiss and / or reduce employees' earnings during quarantine;

- simplified procedure for dismissal and / or reduction of earnings of employees during quarantine; 
- the ban was not introduced, but businesses that maintain the workforce and / or "pre-quarantine" level of earing for employees receive state support;

- the ban was not introduced, but the state provides support to those employees who lost their jobs and / or earnings during the quarantine.

The answers to this block of questions are of very tangible regional specificity: the states of Western Europe and North America provided a positive answer to the question of government support for businesses that retain jobs and wages, as well as the state compensation of part of the lost earnings of employees. The countries of Eastern Europe and the Post-Soviet region gave negative answers to these questions.

3) The state takes measures to support business in connection with COVID 19, which may have negative consequences for employees and / or consumers, residents of the community where the business operates, in particular:

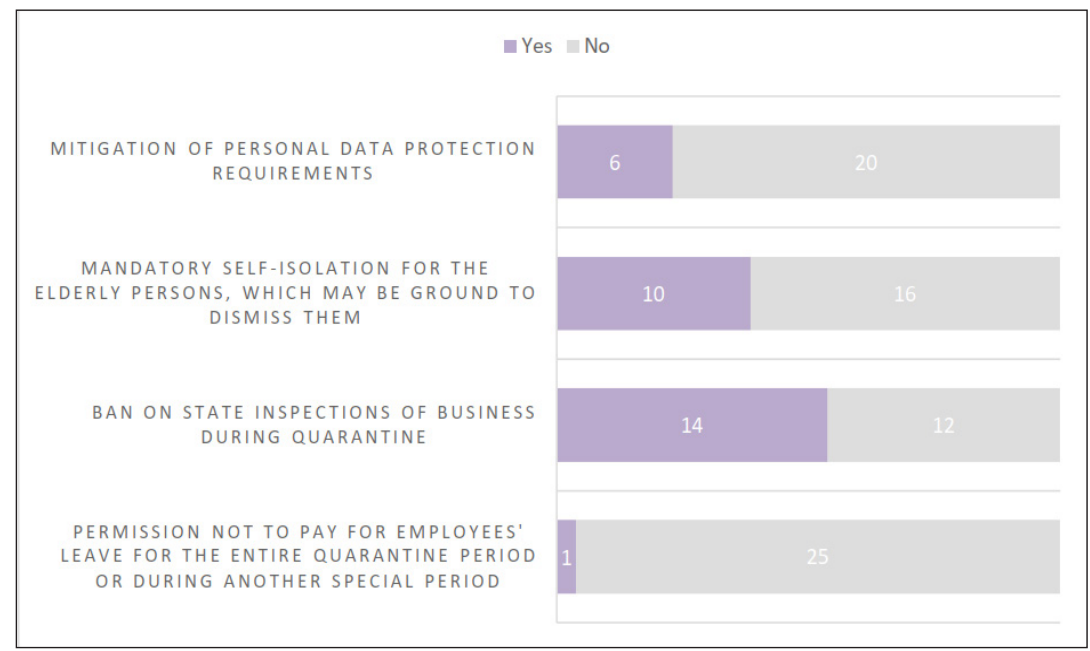

- permission not to pay for employees' leave for the entire quarantine period or during another special period;

- ban on state inspections of business during quarantine;

- mandatory self-isolation for elderly persons, which may be grounds for dismissing them;

- mitigation of personal data protection requirements. 
Easing the requirements for the protection of personal data in connection with COVID 19 is quite typical for the countries of the postSoviet region ${ }^{25}$. In particular, Ukraine has introduced a legislative provision according to which:

the processing of personal data without the consent of the person, in particular data relating to health status, place of hospitalization or self-isolation, surname, name, date of birth, place of residence, place of work (study), is permitted to counteract the spread of coronavirus disease (COVID -19).

Some countries, in particular Ukraine, have worsened the employees position significantly compared to pre-quarantine times by introducing leave for employees without any payment from the employer during all period of quarantine. Formally, the employee uses a leave at will, but in practice this rule is used by companies to save money on wages.

4) The state explains to the business its corporate responsibility to respect human rights, paying special attention to the additional risks associated with COVID 19, which may have various manifestations:

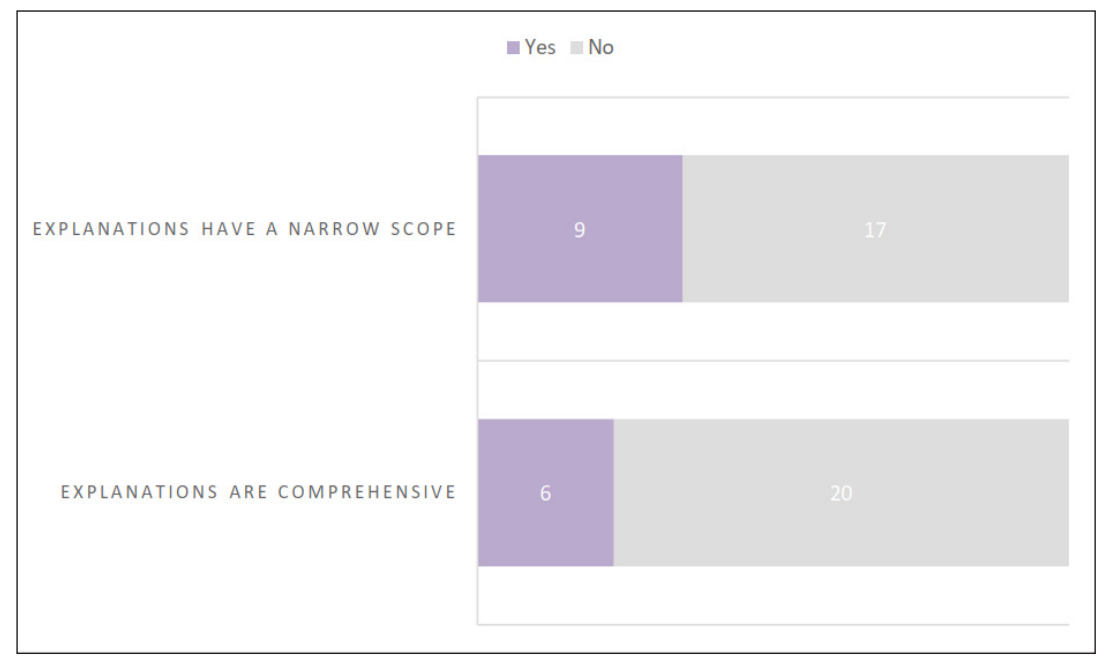

${ }^{25}$ In general, this region includes Azerbaijan, Armenia, Belarus, Georgia, Kazakhstan, Kyrgyzstan, Moldova, the Russian Federation, Tajikistan, Turkmenistan, Uzbekistan, and Ukraine. The survey covered 8 of these countries. 
- State guidelines are complex and cover a wide range of persons whose rights may be affected by business activities and a wide range of business areas;

- State guidelines have a narrow scope (only certain areas of activity and / or categories of business entities and / or for a narrow range of persons affected by business activities).

The situation when experts note the lack of state guidelines for business on risks of human rights violations is typical for all the states covered by the survey. However, if in the countries of North and South America, and Europe such guidelines are present, in many countries they need to be deeper (in particular, there is a lack of guidelines for businesses whose activities affect foreign students, temporary foreign workers, the sex industry etc.). In the post-Soviet countries there are no state guidelines aimed at minimizing the risks of human rights violations by businesses owing to COVID 19.

5) Taking measures by the state to protect gig economy workers (Uber drivers, couriers of delivery services, etc.), in particular:

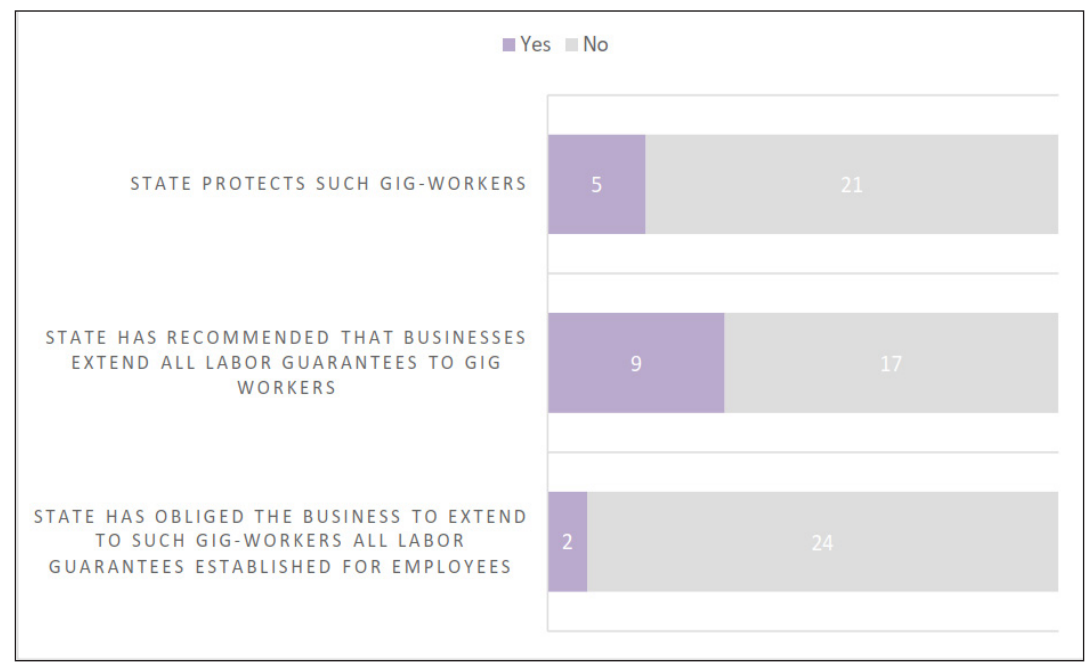

- the state has obliged the business to extend to such gig-workers all labour guarantees established for employees;

- the state has recommended that businesses extend all labour guarantees to gig workers; 
- the state protects such gig-workers (payment of sick leave, granting paid leave, etc.).

As for the vulnerability of gig workers, the existing risks have increased owing to COVID 19. The main difference in the approaches used by states today is the recognition of the problem by some of them (without a universal solution) and complete disregard by others.

It should be noted also that in the Post-Soviet countries, experts note a problem that was not singled out in this survey - the lack of protection of people involved in the informal economy (working without formal employment), the level of which is high. Thus, according to official data, 3.7 million people work informally in Ukraine ${ }^{26}$. Comments received from experts during the survey indicate that similar problems are present in other Post-Soviet countries.

6) Taking measures by the state to minimize the risk of human rights violations by businesses domiciled in this state in the supply chain, including:

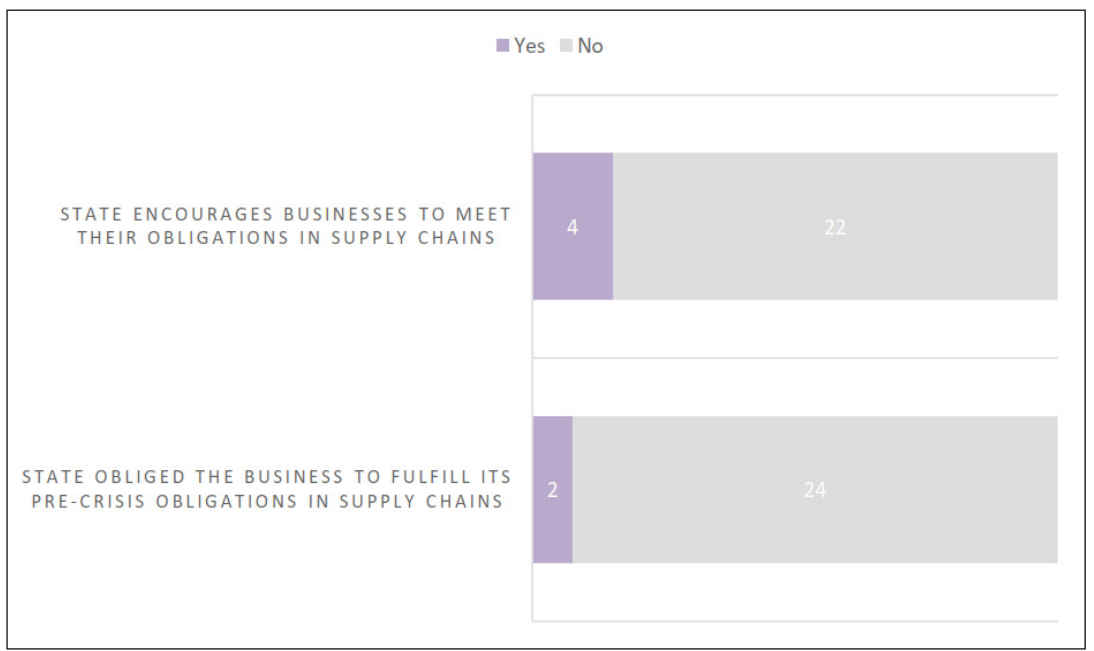

${ }^{26}$ National Baseline Assessment on Business and Human Rightsin Ukraine [inUkrainian], 2019, available at https:/ / minjust.gov.ua/files/general/2019/07/10/20190710170838-51. pdf [last accessed 15.06.2020]. 
- the state obliges the business to fulfil its pre-crisis obligations in supply chains;

- the state encourages businesses to meet their obligations in supply chains.

The survey found that experts who work in the field of human rights, but do not specialize in business and human rights, are not familiar with this problem of human rights in supply chains.

There is also a difference in the perception of this problem in different regions of the world. None of the respondents from the post-Soviet country answered that states are taking measures to draw companies' attention to human rights in their supply chains. This is partly due to the much lower representation of this business model in the region compared to North American and European companies.

7) Taking measures by the state to protect the population from business actions aimed at obtaining unreasonable profits through the sale of goods/ services, the demand for which is high during the crisis, in particular:

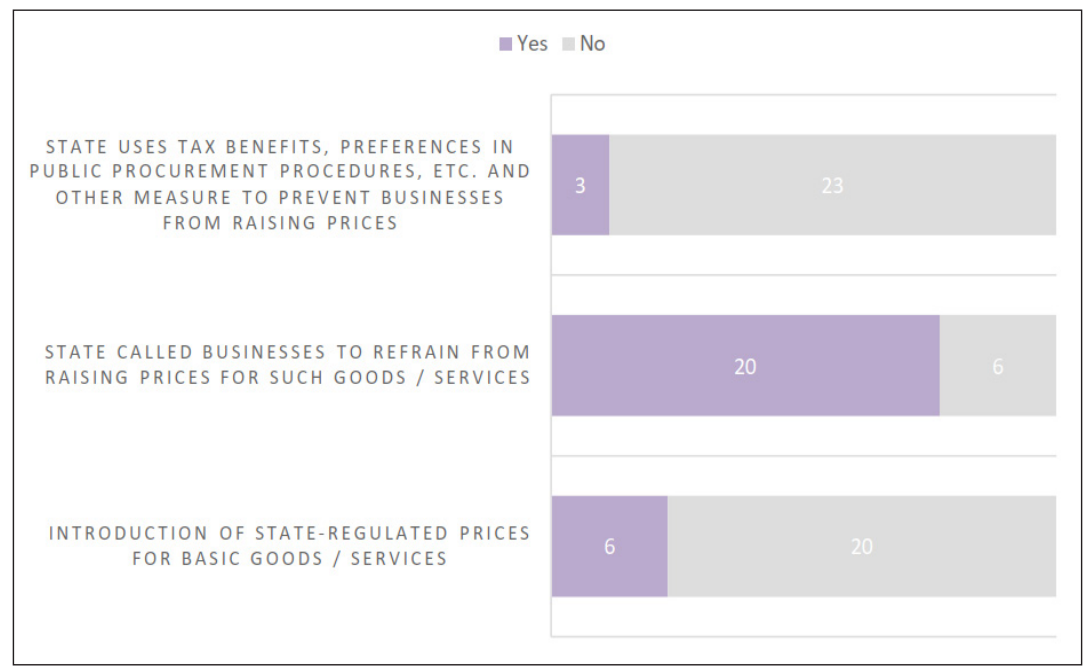

- introduction of state-regulated prices for basic goods/services;

- the state calls on businesses to refrain from raising prices for such goods/services; 
- the state uses tax benefits, preferences in public procurement procedures, etc. and other measures to prevent businesses from raising prices.

In general, the countries of the Post-Soviet region have shown much greater activity in the regulation of prices for goods and services (some of them are classified as socially important), compared to other regions.

8) Taking measures by the state to prevent and promptly eliminate situations when business actions are stigmatizing and/or discriminatory in connection with the pandemic situation, in particular:

- the state points out the inadmissibility of linking the spread of the virus with a particular nation/ethnic group/origin etc;

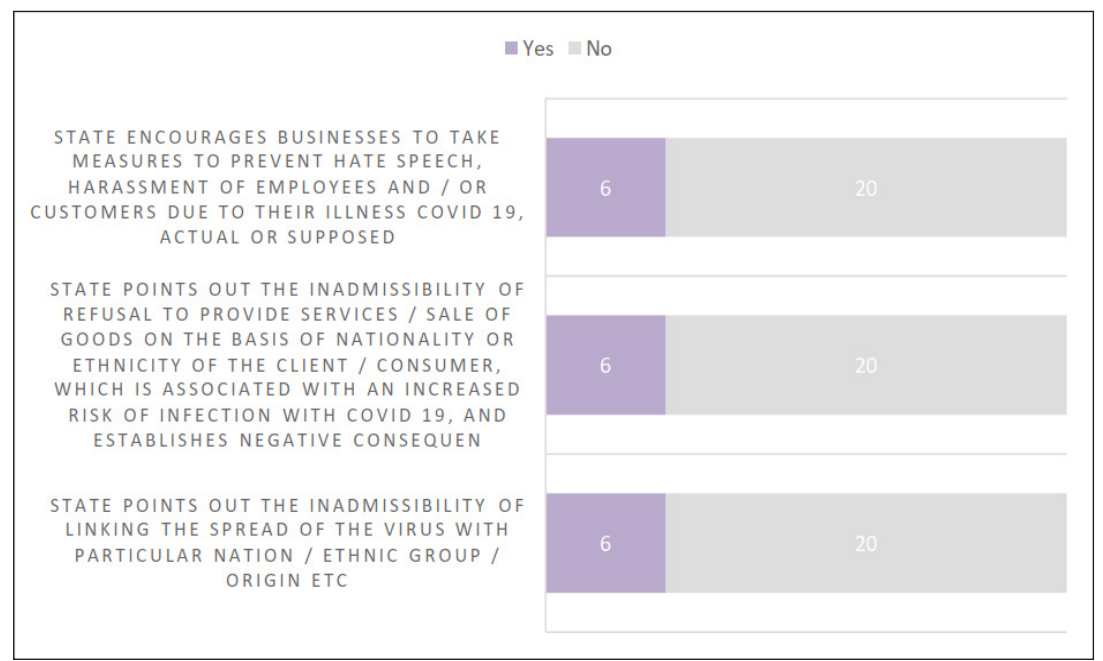

- the state points out the inadmissibility of refusal to provide services/sale of goods on the basis of the nationality or ethnicity of the client/consumer, which is associated with an increased risk of infection with COVID 19, and establishes negative consequences for business in case of violation of this requirement;

- the state encourages businesses to take measures to prevent hate speech, harassment of employees and/or customers owing to their illness COVID 19, actual or supposed. 
Experts from the North American and European regions noted the lack of topicality (relevance) of the issue and the fact that they were unaware of the facts of persecution, discrimination, negative attitude towards people because of COVID 19. At the same time, experts from Post-Soviet countries recognize the problem needs the special attention. They pointed the cases of human rights violations because of association of COVID 19 with a particular national or ethnic group, religious community, as well as harassment owing to illness or suspected illness.

9) The taking of measures by the state aimed at combating false, panicprovoking information, as well as unfair advertising of measures to help with COVID 19, which may include:

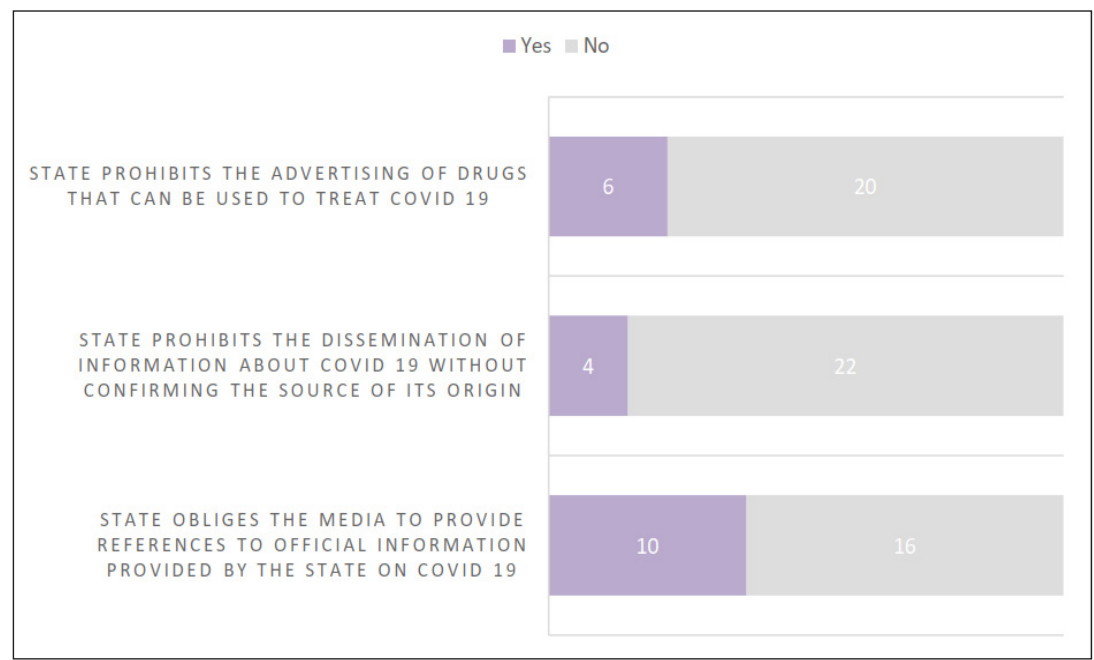

- the state obliges the media to provide references to official information provided by the state on COVID 19;

- the state prohibits the dissemination of information about COVID 19 without confirming the source of its origin;

- the state prohibits the advertising of drugs that can be used to treat COVID 19.

Of the 20 responses received from experts representing the PostSoviet region, 19 noted that the state takes measures to restrict (control) the media and social networks regarding information disseminated about COVID 19. 
10) The state provides employees who worked in the workplace during COVID 19 with the opportunity to use educational services and child care facilities.

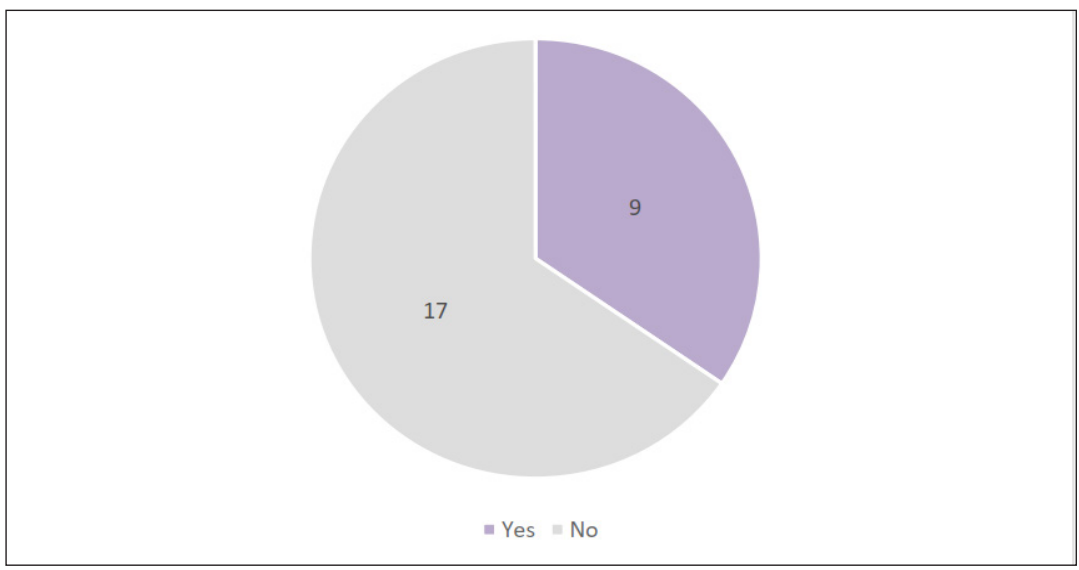

The results of the survey show that educational and childcare facilities operated in some countries to provide opportunities to use their services for those employees who work in enterprises and institutions whose work is recognized as essential (hospitals, pharmacies, grocery stores, transport etc.). There are few examples of states support (payments) for employees who have children because of the unavailability of educational and childcare facilities during the COVID 19. In the countries of the PostSoviet region there was no possibility of childcare during the COVID 19 pandemic, even for people who work is essential. Experts from all regions point out the vulnerability of women in this situation (because of the traditional division of domestic responsibilities / family obligations, which is unequal between women and men), especially women who raise children alone.

11) The state takes into account human rights business conduct during COVID 19 in public procurement procedures, giving tax benefits and other incentives;

$20 \%$ of experts who gave answers about the countries of the PostSoviet region and $26 \%$ of experts from other regions gave a positive answer to this question. However, their comments show that the real percentage is much lower, as in some cases the issue was identified with 
tax benefits and other incentives owing to the situation of COVID 19, without reference to the corporate responsibility to respect human rights.

12) The state analyses how business actions in a crisis of COVID 19 affect vulnerable groups (women, people with disabilities, the elderly persons, workers with children, etc.).

Positive responses were provided mainly for the EU countries and the UK. At the same time, all the experts who responded positively to this question said in their comments that they doubted whether such analysis was carried out by the state in terms of the impact of business actions on vulnerable groups during COVID 19, or whether on the general impact on such vulnerable groups. As for the Post-Soviet countries, experts gave a negative answer to this question. They also pointed out the vulnerability of migrant workers who returned en masse to their native countries (mostly from the EU to the Post-Soviet countries) owing to the crisis. Some of them returned infected with COVID 19.

Experts also recognize the importance of the gender component in the measures taken by states to protect human rights from business violations during COVID 19. In particular, the following factors are highlighted: increased vulnerability of women in global supply chains, women are more represented in low-paid jobs, women are more represented in jobs that are considered as vital, essential, and they continue to work during a pandemic, and women have a greater workload owing to the closure of educational institutions and work at home.

This survey does not cover all aspects of the state's fulfilment of its positive obligation to protect human rights from violations by business, but allows us to indicate the models of legal regulation used by states to implement this task.

Another result of the conducted survey was the confirmation of the fact that experts who do not work with business and human rights issues deny some elements of this concept as it is not covered by the wellestablished understanding of legal regulation, the distribution of power in society, or the perception of state and non-state impact on people's daily lives. Thus, the differences in approaches to the question of the positive obligations of the state to protect human rights from business violations are based on a serious ideological basis for determining the extent of state intervention in the economy as a whole and in the business activities, in particular. This discrepancy was particularly evident in the 
question of the possibility and / or necessity of state regulation of prices of products / goods / services during the COVID 19 pandemic and in the question about state response to the additional risks of discriminatory, stigmatizing impact associated with COVID 19.

Differences in approaches to the state's fulfilment of positive human rights obligations were also reflected in the question of the possibility of the state's using such leverage as tax benefits, preferences in public procurement procedures, etc. to stimulate corporate responsibility to respect human rights. Some experts believe that such a difference in approaches to business entities will be discriminatory.

Some experts deny that the pandemic situation obliges the state to make recommendations to businesses to explain the additional risks to human rights that arise in its activities during the COVID 19. Some respondents indicated that the state's position is sufficient, that an epidemic or other crisis should not have a negative impact on human rights, including situations when such a negative impact is the result of business actions. According to this approach, the state's recommendations are perceived as excessive interference in business activities; the influence of the state on business activities should take the form of legislative norms only. This approach, according to experts, creates guarantees of the rule of law.

A similar approach to non-interference by the state in the freedom of entrepreneurial activity and freedom of contract between a company and a person is reflected in the answers to question on the protection of gig-workers who are extremely vulnerable during COVID 19. The vast majority of experts working outside of the business and human rights agenda are sure that the format of a company's cooperation with a person is determined by both parties voluntarily, and therefore the state should not change such free will.

\section{MOdELS OF REGULATION}

The information we received allowed us to formulate the following characteristics of the regulatory models used by States to meet their obligations to protect human rights from business violations, taking into account the additional challenges associated with COVID 19: 


\begin{tabular}{|c|c|c|}
\hline $\begin{array}{l}\text { Comparison } \\
\text { criterion }\end{array}$ & $\begin{array}{l}\text { A model that takes into } \\
\text { account the business and } \\
\text { human rights concept }\end{array}$ & $\begin{array}{l}\text { A model that operates } \\
\text { without regard to business } \\
\text { and human rights concept }\end{array}$ \\
\hline Leverage & $\begin{array}{l}\text { There are leverages that are } \\
\text { actively used - investors' } \\
\text { position, monitoring } \\
\text { of actions by non- } \\
\text { governmental organizations, } \\
\text { the image of business in } \\
\text { society, the position of } \\
\text { counterparties and so on. } \\
\text { During the crisis it becomes } \\
\text { even more noticeable. } \\
\text { The state also seeks to } \\
\text { actively influence business: } \\
\text { businesses should respect } \\
\text { human rights in return for } \\
\text { receiving state aid (support). } \\
\text { In times of COVID 19, } \\
\text { the state takes into account } \\
\text { the fact that business } \\
\text { faces complex economic } \\
\text { challenges. But the state's } \\
\text { assistance to business is } \\
\text { not provided by easing the } \\
\text { requirements to respect } \\
\text { human rights of employees, } \\
\text { customers, and others, but } \\
\text { it is provided by applying } \\
\text { other instruments that do } \\
\text { not affect human rights } \\
\text { negatively (state aid, tax } \\
\text { benefits, etc.). }\end{array}$ & $\begin{array}{l}\text { There is no leverage } \\
\text { on business that would } \\
\text { encourage it to comply } \\
\text { with the requirements of } \\
\text { corporate responsibility } \\
\text { to respect human rights, } \\
\text { including human rights due } \\
\text { diligence, to identify risks } \\
\text { of human rights violations, } \\
\text { which increase during } \\
\text { crises (investors do not put } \\
\text { appropriate requirements } \\
\text { for business to provide } \\
\text { investment instruments, } \\
\text { society generally does } \\
\text { not link the company's } \\
\text { image with corporate } \\
\text { responsibility to respect } \\
\text { human rights, business } \\
\text { actions are not subject of } \\
\text { human rights monitorings } \\
\text { by non-governmental } \\
\text { organizations, etc.). } \\
\text { State policy is business } \\
\text { friendly. The crisis caused } \\
\text { by COVID } 19 \text { has shown } \\
\text { that states are ready to } \\
\text { implement measures to save } \\
\text { business and worsen the } \\
\text { position of workers. }\end{array}$ \\
\hline $\begin{array}{l}\text { Public } \\
\text { consensus }\end{array}$ & $\begin{array}{l}\text { Societies expect that } \\
\text { business, whether or not the } \\
\text { state makes such demands } \\
\text { on it, bases its behaviour } \\
\text { on standards of corporate } \\
\text { responsibility to respect } \\
\text { human rights. Business }\end{array}$ & $\begin{array}{l}\text { Societies remain state- } \\
\text { oriented in their } \\
\text { understanding of the } \\
\text { human rights mechanisms. } \\
\text { Both society and business } \\
\text { presume that if the state } \\
\text { does not make a certain }\end{array}$ \\
\hline
\end{tabular}




\begin{tabular}{|c|c|c|}
\hline $\begin{array}{l}\text { Comparison } \\
\text { criterion }\end{array}$ & $\begin{array}{l}\text { A model that takes into } \\
\text { account the business and } \\
\text { human rights concept }\end{array}$ & $\begin{array}{l}\text { A model that operates } \\
\text { without regard to business } \\
\text { and human rights concept }\end{array}$ \\
\hline & $\begin{array}{l}\text { sees this requirement as } \\
\text { appropriate. The business } \\
\text { itself declares its desire to } \\
\text { implement the relevant } \\
\text { standards (adopts human } \\
\text { rights policies, introduces } \\
\text { tools to ensure human rights } \\
\text { due diligence, publishes } \\
\text { human rights reports). } \\
\quad \text { At the same time, it } \\
\text { protects the autonomous } \\
\text { space of business actors } \\
\text { from unnecessary state } \\
\text { intervention: the state } \\
\text { leaves the space free from } \\
\text { its regulatory influence, and } \\
\text { business, which understands } \\
\text { better the specifics of each } \\
\text { concrete situation that arises } \\
\text { in its activities, regulates } \\
\text { them autonomously. } \\
\text { This factor is closely } \\
\text { related to the fact that } \\
\text { control over the actions } \\
\text { of business is entrusted } \\
\text { not only to the state: non- } \\
\text { state actors - business } \\
\text { associations, investors, trade } \\
\text { unions, etc. - have effective } \\
\text { tools as well. }\end{array}$ & $\begin{array}{l}\text { requirement, then } \\
\text { business does not have } \\
\text { a corresponding obligation. } \\
\text { As a result, a trap is } \\
\text { formed: on the one hand, } \\
\text { the state cannot regulate all } \\
\text { relations in which business } \\
\text { participates and which are } \\
\text { potentially risky for human } \\
\text { rights, and it cannot foresee } \\
\text { all possible situations, } \\
\text { especially in times of crisis, } \\
\text { on the other hand those } \\
\text { relations which the state } \\
\text { leaves without regulation, } \\
\text { seem to be outside of } \\
\text { human rights requirements. }\end{array}$ \\
\hline $\begin{array}{l}\text { Corporate } \\
\text { social } \\
\text { responsibility }\end{array}$ & $\begin{array}{l}\text { CSR does not replace or } \\
\text { equate business and human } \\
\text { rights standards. CSR as } \\
\text { a charity or other similar } \\
\text { actions takes a back seat: } \\
\text { first of all, business must }\end{array}$ & $\begin{array}{l}\text { In the states of this } \\
\text { regulatory model, it is } \\
\text { common for businesses } \\
\text { to implement the CSR } \\
\text { measures, and at the same } \\
\text { time don't implement }\end{array}$ \\
\hline
\end{tabular}




\begin{tabular}{|c|c|c|}
\hline $\begin{array}{l}\text { Comparison } \\
\text { criterion }\end{array}$ & $\begin{array}{l}\text { A model that takes into } \\
\text { account the business and } \\
\text { human rights concept }\end{array}$ & $\begin{array}{l}\text { A model that operates } \\
\text { without regard to business } \\
\text { and human rights concept }\end{array}$ \\
\hline & $\begin{array}{l}\text { ensure respect for human } \\
\text { rights in its activities. }\end{array}$ & $\begin{array}{l}\text { measures to prevent } \\
\text { negative impact on human } \\
\text { rights. The crisis situation } \\
\text { caused by COVID } 19 \text { has } \\
\text { provided several striking } \\
\text { examples: thus, in Ukraine, } \\
\text { some big companies, which } \\
\text { attracted a lot of media } \\
\text { attention in connection with } \\
\text { the purchase of necessary } \\
\text { materials for hospitals, were } \\
\text { then exposed to corrupt } \\
\text { practices aimed at obtaining } \\
\text { the opportunity to work, } \\
\text { despite the fact that their } \\
\text { activities were prohibited } \\
\text { because of quarantine bans. } \\
\text { CSR continues to play } \\
\text { a leading role, replacing } \\
\text { human rights issues. }\end{array}$ \\
\hline $\begin{array}{l}\text { Tools which } \\
\text { states use }\end{array}$ & $\begin{array}{l}\text { The state uses the following } \\
\text { tools: } \\
\qquad \text { - it encourages } \\
\text { businesses to keep jobs } \\
\text { and the current level of } \\
\text { wages, considering it as } \\
\text { a prerequisite to receiving } \\
\text { state aid by businesses in } \\
\text { connection with COVID 19; } \\
\quad \text { - it makes the receipt } \\
\text { of state aid, tax benefits, } \\
\text { and participation in public } \\
\text { procurement by businesses } \\
\text { dependent on responsible } \\
\text { business conduct; } \\
\quad \text { - it develops } \\
\text { recommendations, }\end{array}$ & $\begin{array}{l}\text { The state uses the following } \\
\text { tools: } \\
\qquad \text { - it facilitates the } \\
\text { business situation by } \\
\text { declaring a business- } \\
\text { friendly approach, by } \\
\text { weakening the guarantees } \\
\text { of protection of the rights } \\
\text { of employees, customers } \\
\text { (labour guarantees, } \\
\text { guarantees of personal data } \\
\text { protection, guarantees of } \\
\text { personal security, etc.); } \\
\text { - it does not make } \\
\text { receiving state aid, tax } \\
\text { benefits by business, its } \\
\text { participation in public }\end{array}$ \\
\hline
\end{tabular}




\begin{tabular}{|c|c|c|}
\hline $\begin{array}{l}\text { Comparison } \\
\text { criterion }\end{array}$ & $\begin{array}{l}\text { A model that takes into } \\
\text { account the business and } \\
\text { human rights concept }\end{array}$ & $\begin{array}{l}\text { A model that operates } \\
\text { without regard to business } \\
\text { and human rights concept }\end{array}$ \\
\hline & $\begin{array}{l}\text { guidelines, and tools for } \\
\text { business on minimizing } \\
\text { the risks of human rights } \\
\text { violations in the context of } \\
\text { COVID 19; } \\
\quad \text { - the state acts in } \\
\text { relations with business } \\
\text { mainly through } \\
\text { recommendations. It leaves } \\
\text { autonomous space for } \\
\text { business to regulate the } \\
\text { relevant area of relations, } \\
\text { based on the human rights } \\
\text { due diligence principle; } \\
\quad \text { - it indicates the impact } \\
\text { of business on vulnerable } \\
\text { groups; } \\
\quad \text { - it responds to new } \\
\text { challenges in the field of } \\
\text { business and human rights } \\
\text { (protection of gig-workers } \\
\text { in times of COVID 19, and } \\
\text { the protection of workers } \\
\text { in supply chains, which } \\
\text { may be disproportionately } \\
\text { affected by the company's } \\
\text { refusal oforders because of } \\
\text { COVID 19, etc.); } \\
\quad \text { - it promotes effective } \\
\text { influence on business by } \\
\text { non-state instruments } \\
\text { (trade unions, business } \\
\text { associations, investors, etc.). }\end{array}$ & $\begin{array}{l}\text { procurement dependent } \\
\text { on human rights business } \\
\text { conduct; } \\
\quad \text { - it does not develop } \\
\text { recommendations, } \\
\text { guidelines, tools for } \\
\text { business on minimizing } \\
\text { the risks of human rights } \\
\text { violations; } \\
\quad \text { - it operates mainly } \\
\text { by setting mandatory } \\
\text { requirements, leaving no } \\
\text { autonomous space for the } \\
\text { regulation by business itself } \\
\text { (this leads to additional } \\
\text { risks of excessive state } \\
\text { intervention); } \\
\quad \text { - it does not pay special } \\
\text { attention to the business } \\
\text { impact on the human rights } \\
\text { of vulnerable groups; } \\
\quad \text { - it ignores new } \\
\text { challenges in the field of } \\
\text { business and human rights } \\
\text { (protection of gig-workers, } \\
\text { protection of workers in } \\
\text { supply chains, etc.); } \\
\quad \text { - there are no non-state } \\
\text { tools to influence business in } \\
\text { the field of human rights. }\end{array}$ \\
\hline
\end{tabular}




\section{CONCLUSIONS}

The pandemic of infectious diseases has been called "the greatest threat to humanity", and many scientists have expressed "concern that the world is not ready to cope with a major pandemic of infectious diseases", long before its occurrence ${ }^{27}$. This thesis is not to reproach states for their unpreparedness, but to consider whether the legal regulation of the actions of the state and other actors in the period of such global challenges can be formed directly during such actions, whether the helplessness of law can be justified by the scale of the problem?

The answer to these questions must lie in the plane of those values that remain valid and relevant, regardless of whether the positive law has time to ensure their effective protection. Human rights are such a value and regulatory basis. But the paradox is that human rights are usually the first victims of a global crisis.

One of the key ideas of the concept of human rights has long been the requirement that the state protect human rights from violations by third parties, e.g. non-state actors. It is manifested in the horizontal effect of human rights. Another thesis is currently less well-established: business should make every effort to prevent human rights violations and ensure respect for human rights in its operations. Both of these requirements - of states and of businesses - are reflected and detailed in the UN Guiding Principles on Business and Human Rights (2011).

The universal nature of human rights determines the universality of requirements for their ensuring, implementation, and protection. In practice, the mechanisms of the realization of human rights are considered through the prism of the development of democracy in a state, its economic situation etc. The global crisis has exacerbated differences in the regulatory models that states use to meet their human rights obligations.

The state's fulfilment of its positive obligation to protect human rights from violations by business must be carried out in accordance with key requirements: balancing the need to ensure public health and human rights protection; balancing the competing rights of non-state actors with

27 Walsh, supra note 1, p. 189. 
taking into account the concept of the right to security as freedom from fear and freedom from want; implementation of the international human rights law requirement on the restriction of human rights, including derogation from international human rights obligations.

COVID 19 has intensified challenges to human rights. Countries with regulatory models that include standards of responsible business conduct are more likely to effectively balance the competing interests of different non-state actors in society, and to offer more flexible and effective tools to respond to global threats. There is a need to strengthen the capacity of governmental and non-governmental institutions to respond to challenges related to COVID 19 or other global challenges. 
